\title{
Taming the Golem \\ - an Experiment in Participatory and Constructive Technology Assessment
}

\author{
Eva Heiskanen
}

This article examines the possibilities and limitations of constructive technology assessment in the light of a CTA-type experiment conducted in Finland on sustainable alternatives for online grocery shopping. The starting point of the analysis is the impasse created by the lack of dialogue between technology proponents and technology opponents. Constructive technology assessment is investigated here as a forum for constructive exchange and co-operation between seemingly antagonistic perspectives on technology. Thus, although the experiment did not provide visible practical outcomes in technology development or market evolution, it was successful in creating an atmosphere of dialogue and creativity that helped technology proponents and opponents to learn from each other.The article concludes that adopting a 'constructive' approach in the sense of making stakeholders work together on envisioning better alternatives appears to be useful in creating new discursive spaces, even when it does not lead to real-world outcomes.

Key words: technology, assessment, participation

Collins and Pinch (2002) frame the imperfect and chaotic nature of technological development using the myth of the golem, the clumsy, unwieldy and havoc-wrecking creature evoked by foolhardy rabbis. A totally contrasting image of technology emerges from the current technology policy discourse. Recent examples of beliefs in the harmonious and progressive nature of technological development are reflected in the EU pro- grammes E-Europe - An Information Society for All and Sustainable E-Europe.

These two opposing frames for technological development are age-old each new century and decade sets them in a new context. In the past few decades, however, technology assessment has started to evolve into a reformist frame, which attempts to take seriously both the progressive and the destructive, the manageable and the unmanageable, 
features of technological change. In recent years, the technology assessment community has also hosted a vigorous movement for participatory technology assessment. New approaches, such as consensus conferences are based on the idea that experts can succumb to dangerous "groupthink" (or even more dangerous "group-do"), and that a healthy dose of layman scepticism and democratic debate is needed to keep technology in harness.

There is also a movement aiming to involve the users and stakeholders of technology in the early stages of technological development, called constructive technology assessment (CTA). It aims to broaden technology development processes by bringing together all interested parties early on, and throughout the design process. Thus, social aspects and problems should gain attention within the process itself. As such concerns usually emerge too late, conventional technology assessment is reduced to "technology arrestment" (Dale and Loveridge, 1996; Cronberg, 1997), with a focus on existing technologies and their negative impacts, rather than users' and society's needs, and the kind of technologies that might help in meeting them.

CTA has been applied both to issues of sustainability (Schot, 1992; Sotoudeh, 2003), and to information technology (Schot, 1999), but not as yet to a combination of these two. Yet ideas about a "sustainable information society" have raised much interest in the US and Europe. The experiment reported here was conducted in the context of a national research programme on the sustainable information society. The specific focus in the study was on online grocery shopping, one of the brainchildren of the in- formation economy. The aim was to see if engaging actors with different perspectives in a constructive assessment process would bring forth new ideas and perspectives on how to integrate ICT and environmental and social sustainability. The article attempts to assess the usefulness of the experiment in terms of two issues: (1) to what extent it succeeded in bringing forth new technology discourses and (2) to what extent it succeeded in actually influencing the development of technology and services in the field.

There is now a significant literature on constructive technology assessment, including a number of empirical case studies (Rip et al., 1995; Cronberg, 1996a; Schot, 1991; Green et al., 1999; Sunderman, 1999; van den Ende et al., 1998; Schot, 2001). Yet the approach has mostly been applied in the Netherlands (Schot, 1999; Guston and Sarewitz, 2002), and there are still many counties in which participatory and constructive TA-approaches have still to make their debut. Finland is one of these (Rask et al., 1999; Miettinen et al., 1999) - a small, late-industrialized country which has recently gained a considerable high-tech reputation. In terms of participatory and constructive TA, the special small-country characteristics have the advantage of dense existing networks of relevant actors, and a consensus style in policy making. Yet a small country with an open economy also has its disadvantages: influential technology-developing companies are large and export-oriented, and there is not much room for technological or economic alternatives. 


\section{Conceptual Background of the Study}

The conceptual background of the study is, broadly speaking, in the "social shaping of technology" literature. The present study is based on a co-constructionist view of technology and society as intertwined and mutually co-constructed. Thus, technological development is not deterministic, but shaped by history, culture and society (MacKenzie and Wajckman, 1994). Yet it also shapes history, culture and society: adopting and discarding technologies is not merely an issue of social preferences (Bijker and Law, 1992). Thus, technological paths can be shaped, but not easily or at will (Williams and Edge, 1995; Bijker, 1995).

Collins's and Pinch's (2002) interpretation of the golem metaphor is within this line of thinking. They do not present the technological golem as monstrous, but as clumsy and difficult to control. Technological and social aspects are so complexly intertwined that any efforts to manage technology completely and in a linear fashion are bound to fail. Yet the solution is not to try to expel the "human factor' from technological development (which is impossible), but to understand the hybrid and imperfect nature of technology, and learn to share responsibility and decisions concerning its development.

In the following, two central themes in this article are presented. First, technology discourses are briefly characterized, and the results of their failure to communicate are discussed. Next, constructive technology assessment is presented as a movement and an action research approach that aims to surmount the gridlock of opposing views and in- terests in the development of technology.

\section{Discourses on Technology and the Environment}

Many authors conceptualize the cultural history of technology and of environmentalism in terms of some kind of explicit or implicit-dialectics. The components in these dialectics can be conceptualized as "discursive frames" (Hård and Jamison, 1998), story-lines (Jamison and Hård, 2003), tides (Cholakov, 1994), or critiques and counter-critiques (Feenberg, 1995).

Since the advent of industrialization, we can identify a "modernist advocacy" of technology, and its "romantic critique" of technology as unhealthy, unnatural and inhumane. During the $20^{\text {th }}$ century, the critical position evolved, and at least two types of critique gained attention. One is the Frankfurt School's "critique of technology as such", which is focused on the unethical nature of the instrumental rationality of technology in itself (Feenberg, 1996). Another, more moderate critique focused on the "externalities" of technology - most notably, since the 1960s, on the environmental damage resulting from the adoption of technologies like synthetic pesticides.

The 1960s also saw the rise of the reformist discourse of "appropriate technology". The term is based on the ideas of E.F. Schumacher about the need for "intermediate technology" to decrease developing countries' dependence on foreign capital and expertise. In the developed world, appropriate technology became a central feature in a social movement linking the peace, environmental and women's movements, and 
arguing for alternative technologies that integrated environmental concerns and human needs into technological development. Self-sufficiency and the importance of local grassroots movements were central tenets in the alternative technology movement, which was the leading discourse of the environmental movement in the 1970s and early 1980s (Phillimore, 2001; Jamison, 2001).

As environmentalism became more mainstream, the environmental critique also shaped a new discourse within, or alongside, the modernist position. Ecomodernism is a reformist school of thought that takes into account the need and possibilities for environmental reform within a modernist and capitalist mode of production. The need for reform is based on the external effects of technology on the environment and human well-being, whereas possibilities for improvement are seen especially in the changing decoupling economic growth from an increasing use of environmental resources. Eco-modernists believe in clean technology, dematerialization of the economy, innovation and green business, and enlightened policies that alter the costs of production factors so that the economy is continually shifted toward a "lighter" and more responsible path in its use of natural resources (Hajer, 1994; Welford, 1998; Heiskanen and Jalas, 2003).

As the original wilderness of the $19^{\text {th }}$ century romanticists has disappeared, and the "appropriate technology" movement has remained relatively marginal (Phillimore, 2001), one could say that the romantic position has subsided into a dystopian one (Feenberg, 1996). Thus, we see very few modern-day people opting out of modern society, or develop- ing technological alternatives. Yet many appear to be sceptical of the ability of science and technology to solve social and environmental problems (Eurobarometer, 2001) ${ }^{1}$. Technological development is viewed by the majority of citizens as inevitable, and as bringing private benefits such as convenience and comfort. On the other hand, it is viewed as permeated by risks and threats to the social order and to the environment (Beck, 1992). Specific technologies and projects encounter resistance, which many view as targeted against the broader techno-economic system as much as against the technology in question. Critiques of technological optimism (including eco-modernism) have continued, and even proliferated, within intellectual and activist circles (Jamison, 2000).

Many authors find the lack of constructive debate between "modernists" (eco- or otherwise) and ecological (and other) critics problematic. Controversies over specific technologies or projects are polarized so that all involved come "to play the role of proponent and opponent" (Schot, 1999), and alternatives are not offered, or considered. In the environmental field, modernists and their critics "have seldom informed one another, their supporters rarely interact or communicate with one another, and they thus have contributed far less than they could have to any comprehensive solution to these serious problems" (Jamison, 2000). Recent research in the social studies of science and technology contests the juxtaposition between technology and culture, and in contrast point to their co-evolution (MacKenzie and Wajcman, 1999). From this perspective, one could redirect the critique of 'tech- 
nology as such' to the instrumental rationality allowed, or assumed, to govern technology at the cost of other, e.g., more communicative forms of rationality. Rip et al. (1995: 10) conclude that "the key is to replace the combination of modernist support and even glorification of technology, and the social, often distant and thus 'outsiders' criticism of technology, by socio-technical criticism".

\section{CTA: an Attempt to Influence the Technology Development Process}

Constructive technology assessment (CTA) is an approach to technology assessment developed in the Netherlands. While its background is in socio-historical analyses of technological development (Bijker, 1995), it aims specifically to tackle the control dilemma formulated by Collingridge (1980): In the early stages of technological development when alternatives are still open, it is too early to foresee the social consequences; whereas by the time the consequences have become visible, the dominant technological solution has become so entrenched that it is extremely difficult to change. CTA also accommodates an evolutionary perspective of technological change (Nelson and Winter, 1982) as a cycle of variation, selection and retention; in which variation occurs mainly within technology development (firms, universities), and selection and retention depend on the environment (markets, society). Thus, developers are often unaware of the social consequences their inventions may have, whereas societal actors are unaware of the kinds of inventions they should be concerned about - until it is too late (Schot, 1992). CTA aims to increase interaction be- tween developers and societal actors in order to address social needs and problems earlier on in the development cycle. CTA can also be seen as a bridge that brings critical voices into the hub of technology development, instead of leaving them 'shouting outside the door'. Technology developers are forced to take the critiques seriously, and critics are forced to take responsibility for finding better solutions. Thus alternative, better designs have a better chance of being created (Schot, 2001).

CTA departs from conventional technology assessment by attempting to be anticipatory, reflexive and conductive to social learning (Schot, 2001). Whereas conventional TA has assumed technology development to be insular, CTA attempts to make the development process inclusive. And whereas conventional TA has considered the public's role (if any) to be that of influencing policy and regulation, CTA attempts to draw the public into the early stages of product development. CTA can thus be considered a step beyond participatory approaches such as consensus conferences (Grundahl, 1997), as it aims not only at clarifying different stakeholders' views, but also at initiating a co-development process.

What exactly is and is not CTA is somewhat ambiguous. Schot (1999) includes participatory approaches such as consensus conferences (which are not necessarily 'constructive', and are usually directed at the regulatory process rather than at design itself). On the other hand, Schot (2001) is quite critical of some processes conducted under the heading of CTA for not being inclusive enough. An edited volume on CTA (Rip et al., 1995) includes a variety of exam- 
ples of development processes that the authors consider to be somewhat in the direction of CTA, and ones that should be made more so. The Dutch Rathenau Institute, formerly closely connected to CTA development, now speaks of Interactive TA (Grin et al., 1997), which has the somewhat less ambitious goal of "providing insights which interested parties can use to influence existing relationships and processes". On the other hand, interactive TA stresses the importance of including all relevant stakeholders, which has not always been the base in CTA projects (Grin et al., 1997). My perspective on CTA follows that of Cronberg (1997) and Schot (2001), who emphasize the participatory and critical aspects of the process.

Perhaps any attempt at constructive technology assessment can at best be viewed as partial and incomplete. Yet one might identify the following points as characteristic to the CTA ethic and logic:

- Inclusion of all interested parties. This of course is problematic. Most CTA examples have included a variety of interested parties (technology developers from companies, universities and research institutes, consumers, NGOs, authorities), usually through representatives. Some have only included consumers, and others have only included companies and authorities (Schot, 2001). The attempt to include all interested parties can be very challenging: examples of parties seldom included, yet potentially with an interest, could be workers in the companies concerned, investors, or people from developing countries.

- Starting at early stage of technology development, and continuing throughout the process. Starting CTA at the early stage of evolution of a technology is based on the idea of technological 'lock-in': when technological networks mature, they are increasingly difficult to change. The focus on continuity aims to keep social concerns on the agenda throughout the evolution of the technology.

- Room to explore social concerns and discuss alternatives. The idea is that technology developers and social stakeholders can together explore the potential social impacts of the technology, which may be difficult to envision early on. On the other hand, alternatives that may be more socially desirable can be considered or taken into the center of the development process. In this respect, CTA emphasizes the role of learning in creating enhanced understandings of technology, and downplays the role of conflicting interests (Wynne, 1995).

- Aim to provide direct influence on the technology development process. While conventional and participatory TA is usually directed at mitigating undesirable impacts through public policy and legislation, constructive TA is directed at an early, pre-legislative stage, and thus aims at more fundamental, albeit voluntary, changes in the development process itself.

Constructive technology assessment is often - although by no means exclusively - discussed in the context of environmental sustainability. The Dutch Sustainable Technology Development programme (Weaver et al., 1998) is one example in which CTA has been applied in this context. The programme aimed to find socially acceptable technological solutions that would help reduce the use of natural resources by a factor of 20 by the year 2025. One of the solutions around which a CTA was built was alternative food protein sources (e.g., fungi, pulses, yeasts and bacteria) as solutions 
to reducing resource-intensive meat consumption. The aim was to identify the most environmentally, socially and economically viable solutions, and get technology development companies and social stakeholders to commit themselves to their development. The CTA process focused on identifying the most promising alternatives, identifying research and development needs, social acceptability criteria and impacts, and gaining the commitment of R\&D organizations and food companies. The process consisted on workshops for stakeholders, which were interspersed with phases of supporting fact-finding and research conducted by the research team co-ordinating the effort.

\section{Participatory and Constructive Technology Assessment in Online Grocery Shopping}

Launching the idea of a sustainable information society represents a CTA-type endeavour to expand the terms in which new technology is evaluated, and import new consideration and actors into the technology development process. Developments in the information economy have many resonances with current environmental ideas such as ecological modernization (Schmidt-Bleek and Lehner, 1999; Heiskanen et al., 2001). In principle, many ICT applications could save energy and other natural resources - distance work and videoconferences could in principle reduce the need for travel, e-business could save energy, mass customization could obviate unnecessary and 'overkill' products, and 'virtual products' could replace physical ones. Yet the golemish face of technology appears to persist in the knowledge economy: as of yet, travel has increased rather than subsided, global materials use continues to grow, and people appear to be using the Internet rather to increase their consumption than to learn about how their choices affect the global environment. Researchers stress the fact that even if there is potential for sustainability in some information society developments, its realization requires a conscious effort and a broader perspective on the impacts of technology (Geels and Smit, 2000; Alakeson et al., 2003). While many theoretical attempts have been made to conceptualize an improved, more sustainable version of the information society (ASIS, 1999; Heinonen et al., 2001; Reisch, 2001), these concepts have not yet been manifested on the level of changes in concrete technologies.

The relationship between the information society and sustainable development has raised research and policy interest in Finland - e.g., in a research programme on the sustainable information society launched by the Ministry of Environment. This programme provided the framework for experimenting with CTA in a Finnish context. We selected online grocery shopping as the focus of the study for a number of reasons. One of these was the need to focus on an application that is 'domestic', so that both suppliers and consumers can be found in the same country - which is today not self-evident in many cases, in which technology developers and users can be very far distanced from one another.

Online grocery shopping is also an example of an ICT application that has raised considerable environmental interest and debate. Firstly, the interest has been in the possibility to reduce traffic 
by obviating the need for private car use for grocery shopping (Orremo et al., 1999; Punakivi and Holmström, 2001). Secondly, online shopping has been viewed as having potential for "ecological transparency" - consumers could be re-connected to producers via detailed product and production information on the Internet (Heinonen et al., 2001). Thirdly, the possibilities of e-business to improve logistics and thus save energy in the delivery chain has gained attention (Romm et al., 1999). Yet studies have also indicated that an environmentally efficient system requires a sufficiently large and centralized clientele and wellcoordinated drop-off times, so that delivery routes can be planned efficiently. Many other uncertainties make it difficult to assess the true environmental potential of electronic grocery shopping: whether it replaces or merely complements supermarkets, whether it actually reduces private car use, and how it influences consumers' ability to select environmentally benign products, as well as how it impacts consumption levels in general (Reisch, 2001). These uncertainties are due to the early stage of development of electronic grocery shopping. At the same time, this early stage makes it possible - in principle - to influence technology and service development so that environmental aspects are taken into account.

The idea in the participatory and constructive TA on online grocery shopping was to find ways to make future developments in online grocery shopping more responsive to environmental and social concerns. Thus, the idea was to help realize the potential for environmental improvement and social wellbeing that the technology promises, while minimizing risks of environmental and social harm. It was conducted as an experiment, the first in its kind in Finland, with a relatively small budget. Thus, we were not quite sure what would come out of it - the aim was to experiment with a CTA-type approach, and evaluate the outcomes of the experiment in order to learn about its possibilities, and introduce this new approach to the Ministry of Environment (Heiskanen et al., 2002; Heiskanen and Timonen, 2003). No external evaluators were involved: the researchers were both organizers and evaluators. The project, however, had a comprehensive steering group with business, administrator and NGO representatives, who participated actively both in the planning and in the evaluation.

The method finally adopted was a combination of participatory and constructive approaches. The aim was to get real-world technology and service developers, consumers, and environmental and social stakeholders together to analyse the current state of online grocery shopping, and try to come up with ideas for a better future in terms of incorporating environmental and social concerns. The work format was designed to create a power-free, constructive atmosphere and ensure participation by all (Susskind et al., 1999). In planning the experiment, we grappled with whether to involve a smaller number of people for a longer period, or have a broader participation but in a more limited timeframe. Most published CTA studies have opted for the former (e.g., Weaver et al., 1999, see also Grin and Graaf, 1997), but we considered the involvement of a broad range of stakeholder (including consumers and NGOs) important in or- 
der to enhance the exploration of alternative solutions.

The project was conducted in the following manner. A booklet of background material was compiled, summarizing the findings of environmental studies, alternative electronic grocery systems available, and existing views on future developments, possibilities and problems in electronic grocery shopping, including a brief discussion on some of the social issues involved (privacy, exclusion, isolation, disabled people, etc.). This booklet was based on a comprehensive analysis of current business models, environmental effects and expert opinions on the topic (Kärnä, 2001). The workshop was introduced as an experi- mental application of a CTA-type approach to the question of sustainability in the information society, with the aim to promote the transfer of ideas about how to increase the sustainability of electronic grocery shopping. It was also highlighted that representatives of key actors who influence the development (e.g. retailers) would be present. Thus, the purpose was not to influence specific policy measures, but rather to raise developers' awareness of social concerns, and search for alternative solutions that accommodate the different concerns and interests.

A variety of actors were invited to a workshop on the issue: all in all, 200 invitations were sent out to retailers, tech-

\section{Table 1. Participants in the workshop on online grocery shopping.}

\section{Group invited}

Business

Experts

Authorities

NGOs

Consumers

\section{Representatives at workshop (number in parentheses)}

retail chains: e-business development, environment (3)

ICT- technology/service companies (2) industry supplying delivery equipment (1) industry association (1) start-up companies (2) venture capital (1)

technical research institutes involved in e-business development (2) other research institutes/units: technology assessment, household technology, agricultural policy, information society statistics (4)

Ministry of Transport and Communications (1) local waste authority (1) national energy advisory agency (1)

environmental (2) social: appropriate technology organization (1) consumer (2)

consumers from National Consumer Research Centre panel (5) young consumer from environmental advisory group (1) 
nology developers, new businesses in the field, authorities, experts, NGOs and consumers from the National Consumer Research Centre's consumer panel. The two-day workshop was organized in May 2002, with 31 participants present, representing retailing and other related business, experts and authorities, and NGOs and consumers (Table 1).

The participants included representatives from the two largest retail chains' e-business units, as well as two researchers from institutes actively involved in developing delivery technology, as well as a person from a company manufacturing delivery equipment. Yet the most successful online retail chain was not able to send a representative, and many other business people and technology developers registered, but were in the end not able to participate due to more pressing business elsewhere. We also found it difficult to attract public authorities (e.g. people from the Ministry of Environment) - partly perhaps because the workshop was organized on two evenings, so that consumers and NGOs would be able to attend after their work. Thus, creating new discourses may be hampered by time-space considerations: for some people, this would be an activity for 'office hours', whereas others can only participate after work.

A large share of the workshop time was devoted to group sessions concentrating on three different issues: efficient deliveries, product information and alternatives to current electronic shopping. On the first day, the groups identified central possibilities, threats and uncertainties in the environmental impact of electronic grocery shopping, whereas the second day focused on developing scenarios for preferable future developments. At the end of both days, the groups convened, presented their findings and had a general discussion.

The workshop was carefully documented, including the following types of material: (1) tape-recordings and transcripts of all working group sessions, (2) material produced by the participants in the workshop (altogether, 248 sheets of paper with questions, ideas, solutions, etc.), different assemblies of these (photographs), and summary charts drawn by participants, (3) notes taken by group facilitators (4) notes taken by organizers in general summary sessions, (5) written feedback from participants at the end of the workshop and (6) interviews with seven participants about six months after the workshop. Interviews were selected as the main means for follow-up due to the experimental nature of the intervention: we were not quite sure what kinds of impacts it would produce, and thus considered an open-ended face-toface discussion the best solution. A special focus was on the impact on technology developers, so representatives of the two largest retail chains and two SMEs were interviewed, as well as two NGO representatives and a representative of the national advisory energy agency. The number of interviews was limited by budget consideration, but informal follow-up in the form of phone-calls and Internet monitoring was conducted for a longer time-period. Obviously, however, the limited amount of follow-up activity and research is one of the most serious limitations of this small-scale experiment. The experiment itself was short-term, and most of the data pertain to immediate or short-term effects.

The data were analysed both in terms of contents (issues raised, ideas gener- 
ated), and in terms of process (roles of participants, contribution to discussion) (Heiskanen and Timonen, 2001) ${ }^{1}$. The special topic of interest in this paper, the debate between technology opponents and proponents, was not originally a special focus in the experiment design or in its evaluation. Yet it became apparent already at the workshop: the participants' views and interests were quite contrasting, yet they managed to create shared ideas. This served to focus part of the interviews and the analysis of the workshop material on the opposing views on technology. For the present paper, the material (that generated by participants, the group session transcripts and the interviews) was analysed in terms of this dimension, and its evolution over the workshop and after it. The analysis is thus grounded in the data (Strauss and Corbin, 1990), even though it is informed by the literature presented in previous sections.

\section{New Technology Discourses?}

During the workshop, the feedback from the participants was encouraging. Positive comments were made on the workshop in terms of providing new ideas and perspectives, including diverse groups and providing new contacts, as well as creating an inspiring and stimulating atmosphere. But was anything new created? This issue can be approached by looking at what participants' original ideas were, and how they developed during the workshop. Table 2 presents an overview of the participants' initial ideas. They were collected by asking people at the start of the workshop to write down things they wanted to discuss in their group. I have classified the papers into six groups on the basis of the topics that they refer to and the perspective that they take on the topic (see examples in column 2).

The topics suggested illustrate the diversity of the participants and their interests. The two largest groups are the "critical" and "practical" ones. They represent two alternative agendas: one critical or reserved, the other committed to developing the technology and services. People raising the first kind of issue often included consumers, NGOs and critical researchers - although some of the sceptical questions were also put forth by people involved in the electronic trade. The second type were often put forth by business people involved in the day-to-day development of grocery retailing or electronic trade - but also by some NGOs, researchers and other experts. Thus, the 'constituency' that people belonged to did not fully correspond to their agendas or initial points of interest. Furthermore, there were topics that do not fall within this dichotomy, such as environmental concerns, consumer needs or policy issues (see "other" in Table 2). Some people also arrived equipped with ideas about alternative solutions to the currently available services, such as mobile interfaces or the possibility to promote local food production.

Although the agendas were by no means clear-cut, one could also distinguish some "enthusiasts" and "sceptics" in the group discussions. Thus, for example, the possibility to distribute groceries directly from warehouses (without the need for retail outlets) was interpreted rather differently by different people. 'Enthusiasts' discussed the possibility for improving delivery efficiency, 
Table 2. Initial agenda of the workshop participants, illustrated by distribution of topics participants suggested for discussion ( $N=101)$

\section{Classification of suggested topic}

Critical issues or sceptical comments

Practical questions

Environmental considerations

Alternative solutions

Consumer needs

Other

\section{Number of \\ suggestions}

29

23

15

15

\section{Examples of suggestions}

Sceptical questions about the future of electronic grocery shopping, or some aspects of it (e.g. profitability of electronic trade, problems in delivering perishable goods). Critical questions on the entireidea of electronic grocery shopping (e.g. "humans 'disappear' in the web", "why investigate this issue from the perspective of sustainable development - it's quite secondary")

Issues related to the practicalities or potential benefits of current electronic grocery shop ping systems (growth prospects of electronic grocery shopping, delivery improvement options, logistics, user interface improve ment, etc).

Topics explicitly referring to environmental benefits or problems in electronic grocery shopping, or in grocery retailing in general (e.g, "possibilities of the Internet to provide environmental information, which is currently difficult to deliver to consumers", "how to improve the supply of organic food in corner shops?")

Suggestions for alternative solutions to the current electronic grocery shopping services (e.g. local delivery centers, new entrepreneurs for local delivery, new user interfaces, possibilities to promote local food production).

Topics related to consumer information, and the kind of information consumers need and use. Items related to consumer attitudes, and the needs of special consumer groups.

Policy issues or the information society in general, or grocery retailing in general (e.g. "the development of trade: global, EU, Finland", "Hypermarkets and local corner shops: opening hours and traffic connections", "number of Internet users - now and in the future?) 
including energy efficiency, reverse logistics and reduced waste. In contrast, critical participants started discussing the kind of working conditions such a delivery system would lead to: "dark, gloomy warehouses in which immigrants would have to work for minimum wages".

It would be too much to say that these different viewpoints converged into a totally new discourse on technology during the two days. Some items simply dropped off the agenda without leaving any trace in the final outcomes of the discussion, and some retained more or less their original form. Yet one can point at a few signs of change in the way people discussed the future of grocery shopping in the information society.

Some people, who were originally very critical toward technological development in general started to find good things that might be supported by the appropriate kind of technology. The following is an illustration of this type of development through remarks made by the same person (a consumer participant) on the first and second day:

Beginning of first day: "And then [in conclusion of a long list of critical questions], I would like to question the humane side of this! So, is technical development humane, irrespective of whether it is environmentally friendly? Are people just doing their work, or is there some meaning in it?"

End of second day: "I went to see a film called "The Land", which is about [rural places in Northern Finland]. It tells a lot about how many farms are really dying. There was this crisis, we joined the EU and people had to learn a new kind of accounting and all that, and it reduced the number of farms drastically ... these kinds of things, then of course this [idea for a service supplying local goods] could make those areas more livable.

On the other side, some of the business people developing electronic grocery services also seemed to have gained some new types of input into their customary way of thinking. Their view was that the environmental and social aspects of electronic grocery shopping had been discussed in a very broad context at the workshop - one that was broader than they were accustomed to within their own organization. One retail service manager interviewed after the workshop made the following comments:

"It was nice, because we had done a large consumer survey in 2001 ...we asked lots of questions about what services electronic grocery shopping could provide, and this event provided information that supported our findings ... but also some things that we had not thought of asking. We do have some 'tunnel vision' here, too. Those comments [at the workshop] imply that perhaps we should broaden our conceptualizations.

[interviewer: about what?] Well, things like organic products, product information and trust in it. And then there was this issue of urban structure: local corner shops vs. hypermarkets. Many participants were surprisingly interested in how to revitalize local shops."

Another stated:

"What was interesting was to find that what you yourself had thought of as a quite innocent thing, a good thing, then others found lots of negative aspects in it ... it was actually quite good that there were some people there from the extreme end of the spectrum, if everyone had been from retailing, it would not have served its purpose." 
Some participants working in environmental communications and research commented on the success of the workshop in terms of raising environmental issues to the agenda. Tired with conventional communications efforts to raise awareness of environmental and energy issues, they considered actively involving people in designing new ideas much more productive.

Some participants came equipped with ideas for alternative ways in which to combine grocery shopping and information technology, i.e. suggestions that departed from the current forms of electronic grocery shopping more or less radically. There were, however, many more alternatives in the final ideas presented by the working groups than there had been in the original suggestions for discussion topics. The final summary of ideas presented included the following suggestions for improving the sustainability of electronic grocery shopping:

Combinations of electronic grocery shopping and local grocery shops in a way that enhances the competitiveness of small shops. There were a number of ideas in this category, but the basic idea was that local shops could maintain a smaller regular stock of products (thus reducing costs), while offering a wide range of products that could be ordered over the Internet (thus improving service quality).

Combined deliveries, including groceries, pharmaceutics, postal delivery, alcohol, and reverse logistics (packaging take-back). These suggestions are especially relevant for Finland, with long distances between consumers and services in many parts of the country (as well as strict legislation forbidding joint transports of many of these items!).
Shared logistics for different retail chains, using one centralized distribution warehouse. This would help reduce inner-city traffic.

Different kinds of user interfaces for electronic grocery shopping, and new places for offering Internet access (local kiosks, laundry rooms, municipal service centers, local shops). The new ideas for interfaces also included youngsters, who are interested and able Internet users, and could make extra money by shopping for older and disabled people, or simply take on more responsibilities at home.

Some tentative ideas on how to organize the provision of reliable environmental information over the Internet (ideas about the division of labour between companies providing the information, authorities certifying it and setting criteria, and user interfaces for more and less interested consumers).

Solutions for supporting local food production, including different kinds of favourites lists, text message alert services for local seasonal foods, specialized portals, etc.

Needs-oriented services catering to the different kinds of needs of different consumers (e.g., variations in requirements for food quality and variety).

Most of these ideas are not totally original in the sense of never having been thought of before. They were, however, new for the participants themselves, or for most of them. They also represent alternatives in the sense that they depart from the mainstream of electronic grocery retailing business models (Cude and Morganosky, 2001; Kärnä, 2001). Furthermore, they deal with environmental aspects more broadly than most published studies on the issue, and take 
an integrated view on the environmental, social and economic dimensions of the problem. For example, the new ideas for Internet access were based on both social (access) and environmental (fewer PCs) considerations. Local shops were considered key in maintaining a livable urban structure, and putting a stop to the increase in traffic and the expansion of urban sprawl.

Yet some participants, although they considered the workshop enjoyable, were slightly disappointed with its outcomes. Perhaps one of the most problematic aspects was that the need to be "constructive" somehow got misrepresented, or misinterpreted, in the workshop process. Although the idea was to encourage people to think about better alternatives, at many points the idea of being constructive somehow came to be directed toward online grocery shopping itself. Many groups spent a lot of time thinking about how to 'rescue' online grocery shopping, and afterwards some people felt that they had not had enough time or space for a fundamentally critical discussion. Thus, the 'consensus' forged appeared in hindsight to have been in part artificial - a temporary space inspired by social interaction and teamwork enthusiasm, rather than a well-reasoned and firm common ground for further action.

\section{Impact on Technology Development}

In spring 2002, the workshop seemed to have provided a forum for lively discussion and a number of innovative ideas. None of these have been implemented yet, however, at the time of writing this article. The impacts of the workshop were investigated by interviewing seven of the participants about half a year after the event. These interviews indicated that the impact of the workshop on participants' daily work had been quite modest. At best, it had provided some new ideas that were 'simmering on the back plate', as the following examples from interviews with business representatives indicate:

"Ninety-five per cent of the ideas presented [at the workshop] were old ones that have been discarded as infeasible. Two percent were ideas that we have considered and abandoned. The remaining three percent were actually new. For example, the idea of providing different customer groups with different kinds of user profiles [product selection, distribution mode]...The possibility to provide environmental information over the Internet was new, too...And the co-operation between retail chains got a little more momentum, once again."

"Who makes things change? It should start with public debate, and make consumers raise their voice, and then make the whole chain react ... this seminar was good for that kind of thing, and I have continued to think about the development of information technology from that perspective."

One of the reasons for the modest impact of the workshop may relate to timing. The end of the 1990s had been the time of the great information technology boom. Many new companies and business ventures had been started with high hopes. In the following few years, a number of these businesses collapsed. In 2001 and 2002, some online grocery retailing companies had shut down their operations, and many more had their ebusiness 'on hold'. Thus, there were few resources available for launching new 
innovations, and can be seen in the following quote:

\begin{abstract}
"Most of the things said in the discussion supported my own views on the state, problems, hopes and opportunities of electronic trade. To my surprise, I also heard suggestions that Ekoportti [company providing local and organic food online], which I represent, has already been offering. Unfortunately, we don't have any resources left now to improve, advertise, etc. our service."
\end{abstract}

Another reason for the lack of impact on technology development probably relates to the workshop design. We hoped the workshop would stimulate some of the participants or the Ministry of Environment to take the next step. Yet all of the participants have other daily concerns than building up a sustainable grocery delivery system for the future. Each of the 31 participants also represented only a small fraction of their reference group. Thus it seems that in order to achieve visible impacts on the technology, we as organizers should have focused more on building a durable interest coalition.

With a small budget and a limited time-frame, it is also somewhat accidental who participates ${ }^{2}$ and what follows. It was interesting to note that the clearest influence of the workshop was on the work of someone who did not manage to attend, although he had signed on to attend the workshop. This was a manager from a co-operative retail chain, Tradeka, with many small local shops. He was sent the summary report of the workshop. As a consequence, the retail chain in question decided to publish, in August 2002, a plan they had been sitting on for some time. The plan was for a combination of local corner shops and
Internet grocery retailing, much in line with the ideas of some of the workshop participants. Yet grocery retailing in Finland soon got caught up in yet another shakeout of mergers and foreign competition, pushing aside any innovative ideas. This experience seems to be 'one up' for the 'golem view': sustainable technological development obviously cannot be steered by a handful of idealists in a world in which there are always more pressing concerns and more important interests.

In fact, the workshop turned out to be closer to the ideas on "interactive technology assessment” presented by the Rathenau Institute (Grin et al., 1997) than Schot's $(1999 ; 2001)$ more ambitious goals of actually influencing the technology development process in the long term. The authors from the Rathenau Institute have highlighted some of the limitations of "interactive TA". Firstly, the participants are naturally only a selection of the people involved in and impacted by the technology in the real world. Thus, it may be too much to expect that the learning process and meaningful outcomes reached at a workshop are translated in any direct form into processes occurring outside it. Secondly, interactive TA is a kind of social experiment carried out in as powerfree context as possible - in the real world, however, there are existing power relations and vested interests. Interactive TA can at best provide new insights for the interested parties. Thus, interactive TA can influence processes of policy judgment and technology development, but it cannot replace or fully play out these processes.

The experiences gained from the Finnish workshop on online grocery 
shopping agree with these reservations: at best, some common ground was created between opposing discourses, yet the impacts in the real world still remain to be seen. Many participants were inspired by the diversity of viewpoints present at the workshop, and its constructive approach. As of yet, none have however made the effort to continue the process in a self-organized manner. In the case of grocery retailing, there is not much public pressure to improve online retailing systems, or to salvage local corner shops. Even when pressure is present, it is usually local, whereas the technology developers and appliers (retail chains) are nation-wide or international, and define their competitive strategies in terms of pricing policy and streamlining retail outlet concepts. Small entrepreneurs, on the other hand, are struggling to survive, and have few resources for long-term future-oriented efforts. In a small, open economy dominated by a few large companies, it is difficult to encourage the development of technological alternatives.

\section{Discussion: Inching Toward a New Technology Discourse}

In some of the literature (Schot, 1992; Sunderman, 1999), CTA is presented as a tool-like method to reach specified outcomes. Practical experience indicates that this is quite ambitious, as there are so many actors and considerations influencing the technology development process. There are also vested interests to consider, whereas CTA accentuates the cognitive function of participatory $\mathrm{TA}$ - discovering unanticipated impacts and uncovering unexplored alternatives. It is quite obvious that not everyone wants to discover potential social problems related to their technologies, or reveal all aspects of their development plans that are relevant for the analysis. This is an issue that should be addressed more seriously in further research.

Compared with the outcomes of previous CTAs aiming to promote sustainability the results of our experiment were quite modest. We focused more on bringing in a breadth of different angles and ideas (the "variation" stage), and less on developing durable coalitions (the "selection" and "retention" stages). Thus, our outcomes were fairly similar to those reported by Quist and Vergragt (2000) in the SusHouse project, which aimed to discover and analyse sustainable alternatives for different areas of consumption (e.g., eating, clothing care and housing), and provided mainly ideas for further development by the business community and policy makers. Other projects, e.g. the "novel protein" CTA reported in Weaver et al. (1999), and projects in the field of "transition management" (Elzen et al., 2004), such as the Finnish "societal embedding" projects by Kivisaari et al. (2004), have focused more on the "selection" and "retention" stages, and consequently, been more successful in actually shaping technological development. These projects have been more long-term, ongoing cooperation efforts focusing on adapting specific technologies to the needs of users and society.

So the experiment reported here is clearly a mixture of participatory and constructive elements, which only encompasses the first stage of adapting technological innovations to society's needs. Yet it demonstrates that a con- 
structive approach (i.e. the attempt to envision better technological futures and develop shared designs in a participatory process) may enhance participatory TA even if it does not lead to immediate 'real-world' changes. The attempt to create better alternatives together helps to create a space for dialogue between different technology discourses.

The lack of communication between different ways of thinking about technology seems to be a real problem in developing a sustainable information society, and perhaps, in introducing sustainable innovations more generally (Timonen $e t$ al., 2003; Heiskanen et al., 2004). Ideas linking technological development and sustainability may be quite clever on the drawing-board, but they seem to have failed to convince the majority of either industry players or environmentalists, not to mention ordinary consumers. Both modernist and critical views of technology tend to see linear developments, proponents and opponents, and both fail to see alternatives or believe in their feasibility. Of course, there are real impediments to technological alternatives, such as technological lock-ins and the returns on scale contributing to the emergence of dominant designs (Arthur, 1989). But technological alternatives also require social movements and unexpected arrays of humans and artefacts (Latour, 1996).

According to Schot (2001), CTA should help technology developers and stakeholders to learn to articulate, but also question existing market demands and regulatory requirements. This goal seems to have been met, at least to some extent, in the workshop reported here. The evocation to 'develop wild ideas' on the second day of the workshop led to alternative designs that certainly question many existing market demands and even regulations. Why can't different kinds of products (e.g. medicine, post, food, alcohol, recyclables) be delivered in one load? Why don't competing retail chains co-ordinate their logistics? What could be done to stop the extinction of local corner shops? Thus, even in a small country with dense social networks, interventions like the workshop seem to be important in creating new ways of thinking. This appears to be because new ways of looking at technological development require new connections not only between different people, but also between different people, things, and discursive frames or modes.

The experiences with the CTA workshop indicated that making technology proponents and critics work together does not necessarily translate into realworld outcomes. Yet I suggest, that on a larger scale, the diffusion of such co-design practices might lead to the following beneficial outcomes:

Working together, rather than debating, promotes "boundary-spanning practices" (Wenger, 1998) by having stakeholders with divergent views actually participate (for a short period) in each others' social worlds.

Involving critics early on in the development process might help technology developers to question their own views, which are often flavoured by "groupthink" phenomena. Social movements are, in fact, quite important in technological development (Laurila, 1997), but diversifying the membership in such movements might help in making technological development more responsive to social needs.

By being invited into the world of tech- 
nology development, critics and nonusers may find a new angle on the technology - thus also increasing the variety of ways in which technology can be appropriated and promoting user activism (or "technological citizenship", Frankenfeld, 1992) in society.

I suggest that interventions like the CTA workshop may be one way to start such new movements and create new discursive spaces. By trying to design things together (rather than merely talk), the diverse participants were forced to open their minds to unfamiliar perspectives. At least for a moment, a tiny area of common ground was created for technology advocates and critics. The experiment underlined that such short-term co-development processes are but one step, and transferring the ideas into the 'real world' is another, much larger effort. I would argue that this step - encouraging co-design by people with opposing views - can be useful in broadening the scope of such further efforts by drawing on the knowledge and values of people who are not "technology enthusiasts". Such interventions can provide a space for critics to present their views in a way that can be "heard" by technology developers as an input - and not only as an obstruction - for the technology development process (Cronberg, 1996b).

\section{Aknowledgements}

The study was conducted with financial support from the Ministry of Environment (Environmental Cluster Research Programme on Sustainable Information Society) and the National Consumer Research Centre. The co-operation of colleagues Päivi Timonen and Petteri Repo (National Consumer Research Centre) and Mikko Jalas, Susan Meriläinen and
Anu Valtonen (Helsinki School of Economics) is gratefully acknowledged, as well as the help of countless people who contributed to the planning and organising of the workshop.

\section{Notes}

1 European citizens appear to be somewhat divided, in general, on the benefits and risks of science and technology. In an EU survey, most respondents did consider science and technology would help combat diseases, improve daily life and make work more interesting. Yet many were also of the opinion that science and technology create problems that they cannot easily solve themselves, such as environmental and social problems. See Eurobarometer (2001). Europeans, science and technology. Eurobarometer 55.2. European Commission, Research Directorate-General.

2 Original dimensions in the data analysis were (1) process and participation, and (2) outcomes and their impacts. Process and participation was analysed by first analysing all the feedback on the process gained directly (in writing) at the end of the workshop, and all comments on the process stated in the interviews. These were done by grouping statements first into positive and negative, and then considering the reasons stated for these comments. Here, already, the notion of divergent viewpoints emerged as a positive, but surprising aspect, for many participants. Then, a sample of all groupwork session transcripts $(5 / 10)$ was coded to establish the number of times representatives of different interest groups made comments in the group sessions. This indicated that company representatives and experts were somewhat more vocal, but that consumers and NGOs managed to voice their views quite frequently, as well. An analysis was also conducted of how different interest groups interacted, i.e., from what subject position they spoke. The topic of whether critical viewpoints managed to be heard was analysed by comparing the 
participants' original suggestions for discussion topics and the groups' conclusions (written and visual) at the end of both sessions, and our notes from the concluding discussions. Here we found that some critical viewpoints had disappeared during the course of the workshop, some retained their original form, but others had been integrated into new design ideas. The analysis in the present articles is an elaboration of this last category of ideas by restudying the groupwork session transcripts and developing a more systematic categorization of initial viewpoints and perspectives found in the final ideas presented.

\section{References}

Alakeson, V., AldrichT., Goodman, J. \& Jorgensen, B.

2003 Making the Net Work: sustainable development in a digital society. UK: Xeris Publishing Company.

Arthur, W.B.

1989 "Competing technologies, increasing returns and lock-in by historical events."

ASIS The Economics Journal 99: 116-131.

1999 Alliance for a Sustainable Information Society. New Horizons for Research, Politics and economy in a Sustainable Information Society. CEC Deliverable WP2D4.

Beck, U.

1992 Risk Society. Towards a New Modernity. London: Sage.

Bijker, W.

1995 Sociohistorical Technology Studies. In. Jasanoff, S., Markle, G. E., Petersen, J.C. \& Pinch, T. (Eds.) Handbook of Technology Studies. Thousan Oaks, London \& New Delhi: Sage.

Bijker, W. \& Law, J.

1992 Shaping Technology, Building Society. Studies in Sociotechnical Change. Cambridge, Mass: MIT Press.

Cholakov, V.

1994 "The Tides of Environmentalist Discourse." Science Studies 7 (1): 31-46.
Collins, H. \& Pinch, T.

2002 The Golem at Large. What Your Should Know about Technology. Cambridge: Cambridge University Press.

Cronberg, T.

1996a "European TA-Discourses-European TA?". Technological Forecasting and Social Change 51 (1): 55-64..

1996b "Do Marginal Voices Shape Technology?" In: Joss, S., Durant, J. Public Participation in Science. The Role of Consensus Conferences in Europe. Science Museum, London.

1997 "Why do we always have to say no?" In: Moser, I. \& Aas, H. (eds.), Technology and Democracy: Gender, Technology and Politics in Transition. Oslo: Centre for Technology and Culture.

Cude, B.J. \& Morganosky, M.A.

2000 "Online Grocery Shopping: An Analysis of Current Opportunities and Future Potential." Consumer Interests Annual 46: 95-101.

Dale, A. \& Loveridge, D.

1996 Technology Assessment - Where Is It Going? International Journal of Technology Management, Special Issue on Technology Assessment: 715-722.

Elzen, B, Geels, F. W. \& Green, K.

2004 System Innovation and the Transition to Sustainability - Theory, Evidence and Policy. Cheltenham: Edward Elgar.

Feenberg, A.

1995 Alternative Modernity. The Technical Turn in Philosophy and Social Theory. Berkeley: University of California Press.

Feenberg, A.

1996 "Marcuse or Habermas: Two Critiques of Technology." Inquiry 39: 45-70.

Fishbein, B.

2000 "The Internet and e-Commerce: A New Imperative for EPR." In: Fishbein, B., Ehrenfeld, J. \&Young, J. (eds.) Extended Producer Responsibility: A Materials Policy for the 21st Century. NYC: Inform, Inc.

Frankenfeld, P.

1992 "Technological Citizenship: A Normative Framework for Risk Studies." Science, Technology and Human Values 17(4): 459-484. 
Geels, F.W. \& Smit, W.A.

2000 "Failed Technology Futures: Pitfalls and Lessons from a Historical Survey." Futures, 32 (9/10), 867-886.

Grin, J., Graaf, H. \& van de Hoppe, R.

1997 Technology Assessment Through Interaction : A Guide. The Hague: Rathenau Institute.

Grundahl, J.

1997 "The Danish Consensus Conference Model." In S. Joss, J. Durant (Eds.) Public Participation in Science. London, Science Museum.

Green, K., Hull, R., McMeekin, A. \& Walsh, V. $\mathrm{xxx}$ ? "The construction of the techno-economic: networks vs. paradigms." Research Policy 28 (7): 777-792.

Guston, D.H. \& Sarewitz, D.

2002 "Real-Time Technology Assessment". Technology in Society 24 (1-2): 93-109.

Hård, M. \& Jamison, A.

1998 The Intellectual Appropriation of Technology. Discourses on Modernity, 19001939. Cambridge, Ma: MIT Press.

Heinonen, S., Jokinen, P. \& Kaivo-oja, J.

2001 "The Ecological Transparency of the Information Society." Futures 33: 319337.

Heiskanen, E. \& Jalas, M.

2003 "Can services lead to radical eco-efficiency improvements? - a review of the debate and evidence." Corporate Social Responsibility and Environmental Management 10 (4): 186-198.

Heiskanen, E., Halme, M., Jalas, M., Kärnä, A. \& Lovio, R.

2001 Dematerialization: the potential of ICT and services. Helsinki: Ministry of the Environment: Finnish Environment: 533.

Heiskanen, E. \& Timonen, P.

2003 Kohti kestävää tietoyhteiskuntaa? Päivittäistavaroiden verkkokaupan osallistuvan ja rakentavan teknologian arvioinnin kokeilu (Toward a sustainable information society? - An experiment in participatory and constructive technology assessment of online grocery shopping). Helsinki: National Consumer Research Centre 2003:8.
Heiskanen, E., Timonen, P., Niva, M. \&

Aalto, K.

2002 "Promoting Sustainable Product Culture and Consumption." In: Hertwich, E. (ed.) Lifecycle Approaches to Sustainable Consumption. Workshop Proceedings 22 November 2002. Laxenburg: International Institute for Applied Systems Analysis, Interim Report IR-02-073.

Jamison, A. \& Hård, M.

2003 "The Story-lines of Technological Change: Innovation, Construction and Appropriation.” Technology Analysis \& Jamison, A. Strategic Management 15 (1): 81 - 91.

2000 "On the Ambiguities of Greening." Innovation: The European Journal of Social Sciences 13 (3): 249-264.

2001 The Making of Green Knowledge. Environmental Politics and Cultural Transformation. Cambridge: Cambridge University Press.

Kivisaari, S., Lovio, R., Väyrynen, E.

2004 "Managing experiments for transition. Examples of societal embedding in energy and health care sectors". In Elzen, B., Geels, F. \& Green, K. (eds.) System Innovation and the Transition to Sustainability: Theory, Evidence and Policy. Cheltenham: Edward Elgar Publishing.

Kärnä, A.

2001 "Dematerialization potential of electronic grocery shopping." In: Heiskanen, E., Halme, M., Jalas, M., Kärnä, A. \& Lovio, R. (2001). Dematerialization: the potential of ICT and services. Helsinki, Ministry of Environment: Finnish Environment 533.

Latour, B.

1996 Aramis or the love of technology. Cambridge: Harvard University Press.

Laurila, J.

1997 "The Thin Line Between Advanced and Conventional New Technology: A Case Study on Paper Industry Management", Journal of Management Studies 34 (2): 219-

MacKenzie, D. \&Wajcman, J. (eds.)

1994 The Social Shaping of Technology. Buckingham: Open University Press. 
Miettinen, R., Eela, R. \& Rask, M.

1999 "The Emergence and Institutionalisation of Technology Assessment in Finland." Science Studies 12 (2): 48-63.

Orremo, F., Wallin, C., Jönson, G. \&

Ringsberg, K.

1999 IT, mat och miljö - en miljökonsekvensanalys av elektronisk handel med dagligvaror. (IT, food and environment - an environmental assessement of electronic grocery trade). Stockholm: Naturvårdsverket 5038.

Phillimore, J.

2001 "Schumpeter, Schumacher and the Greening of Technology.” Technology Analysis and Strategic Management 13 (1): 23-38.

Quist, J.N. \& Vergragt, P.J.

2000 "System Innovations towards Sustainability Using Stakeholder Workshops and Scenarios". Paper for Policy Agendas for Sustainable Technological Innovation. 3rd POSTI International Conference, London, UK, 1-3 December, 2000.

Punakivi, M. \& Holmström, J.

2001 Environmental performance improvement potentials by food home delivery. NOFOMA 2001 Conference Proceedings, June 2001. Available on the Internet at http:/ / www.tuta.hut.fi/ecomlog/

Rask, M., Eela, R., Heikkerö, T. \& Neuvonen, A.

1999 Teknologian arviointi, arvot ja osallistuminen - kokemuksia geenitekniikkaarvioista. (Technology assessment, values and participation - experiences from genetic technology assessement). VTT Group on Technology Studies, Working Papers 45/99. Espoo: VTT.

Reisch, L.A.

2001 "The Internet and Sustainable Consumption: Perspectives on a Janus Face." Journal of Consumer Policy 24 $(3 / 4): 251-286$.

Rifkin, J.

2000 The Age of Access. New York: Penguin Putnam.

Rip, A., Misa, T.J. \& Schot, J.

1995 Managing Technology in Society. The Approach of Constructive Technology Assessment. London \& New York: Pinter Publishers.
Romm, J., Rosenfeld, A. \& Hermann, S.

1999 The internet economy and global warming. A scenario of the impact of e-commerce on energy and the environment. The Center for Energy and Climate Solutions, a division of the Global Environment and Technology Foundation. Version 1.0, December 1999. http://www.cool-companies. org/ecom/pr.cfm.

Schmidt-Bleek, F. \& Lehner, F.

1999 Die Waschstumsmaschine. Munchen: Droemer.

Schot, J.W.

1992 Constructive Technology Assessment and Technology Dynamics: The Case of Clean Technologies." Science, Technology and Human Values, 17 (1), 36-56.

Schot, J.W.

1999 "Constructive Technology Assessment Comes of Age. The Birth of a New Politics of Technology." Proceedings of the 1999 International Summer Academy on Technology Studies. IFF/IFZ InterUniversity Research Center for Technology, Work and Culture. Available on the Intenet: http://www.ifz.tu-graz. ac.at/sumacad/schot.pdf.

Schot, J.W.

2001 "Towards New Forms of Participatory Technology Development.” Technology Analysis and Strategic Management 13 (1): 39-52.

Sotoudeh, M.

2003 "Participatory methods: a tool for the improvement of innovative environmental technologies." International Journal of Environmental Technology and Management 3 (3/4): 336-348.

Strauss, A.L. \& Corbin, J.

1990 Basics of qualitative research: grounded theory procedures and techniques. Newbury Park: Sage.

Sunderman, K.

1999 "Constructive Technology Assessment" In S. Bröchler, G. Simonis, K. Sunderman (eds.): Handbuch Technologiefolgenabschätzung . Berlin, Ed Sigma.

Susskind, L., McKearnan, S. \& Thomas-

Larner, J.

1999 The Consensus Building Handbook: A Comprehensive Guide to reaching Agreement. 
Timonen, P., Mäkelä, J., Niva, M., Hyvönen, K. \& Vesmanen, E.

2004 Tulevaisuuden keittiö. (The kitchen of the future). Publications 1/2004. National Consumer Research Centre, Helsinki. Available online at: http://www. kuluttajatutkimuskeskus.fi/docs/pdf/ julkaisu_2004_1_tulevaisuuden_keittio.pdf. [referenced May 31, 2004].

van den Ende, J., Mulder, K., Knot, M., Moors, E. \& Vergragt, P.

1998 “Traditional and Modern Technology Assessment: Toward a Toolkit - A Research Methodology and Learning Strategy for Social Impact Assessment". Technological Forecasting and Social Change 58 (1): 5-12.

Väyrynen E., Kivisaari S. \& Lovio R.

2002 Juurruttaminen uusiutuvien energioiden käytön ja energian säästön edistämisessä. (Societal embedding in the promotion of renewable VTT Tiedotteita 2175.

Weaver, P., Jansen, L., van Grootveld, G., van Spiegel, E. \& Vergragt, P.

1998 Sustainable Technology Development. Sheffield: Greenleaf Publishing.

Welford, R.

1998 "Corporate Environmental Management, Technology and Sustainable Development. Postmodern Perspectives and the Need for a Critical Research Agenda." Business Strategy and the Environment 7 (1): 1-12.

Wenger, E.

1998 Communities of Practice: Learning, Meaning and Identity, Cambridge UP.

Williams, R. \& Edge D.

1996 "The Social Shaping of Technology" Research Policy 25: 865-899

Wynne, B.

1995 "Technology Assessment and Reflexive Social Learning - Observations from the Risk Field.” In Rip, A., Misa, T.J. \& Schot, J. (eds.) Managing Technology in Society. The Approach of Constructive Technology Assessment. London \& New York: Pinter Publishers.
Eva Heiskanen

National Consumer Research Centre, Helsinki, Finland eva.heiskanen@ncrc.fi 